\title{
Pengenalan Dan Klasifikasi Citra Tekstil Tradisional Berbasis Web Menggunakan Deteksi Tepi Canny, Local Color Histogram Dan Co-Occurrence Matrix
}

\author{
I Putu Gd Sukenada Andisana ${ }^{1}$, Made Sudarma ${ }^{2}$, I Made Oka Widyantara ${ }^{3}$
}

\begin{abstract}
Indonesian textile motifs is influenced by elements of nature, environment and culture that develop in the community. Materials, motifs and techniques for making traditional textiles are different from one region to another. The use of information technology in preservation and providing knowledge to the public can made in the form of software that can match the pattern of images or photos while performing traditional textile classifications. The input in this study is an image of a patterned texture. The software through the pattern recognition process will perform calculations and produce values that can be matched in the sample database that has previously been processed. The method used is the color feature extraction with the Local Color Histogram method, texture feature extraction with the Co-occurrence matrix method, and the extraction of shape features with the Canny Edge Detection method. Each feature extraction will produce a vektor. The data used consisted of 10 textile groups namely endek bali, songket bali, tenun dayak, tenun ikat, sasirangan, kain besurek, ulos, sutera bugis, kain gringsing. Classification method by using K-Nearest Neighborhood (K-NN). The results of the study show that the average value of the product known in accordance with the textile group is $\mathbf{8 8 . 0 3 \%}$. The highest value using texture feature extraction is $99.37 \%$ and the lowest is $63.75 \%$ by using feature and color feature extraction.
\end{abstract}

Intisari- Penggunaan motif tekstil tradisional Indonesia dipengaruhi oleh unsur-unsur alam, lingkungan dan kebudayaan yang berkembang di masyarakat. Material, motif, dan teknik pembuatan tekstil tradisional dapat berbeda antara satu daerah dengan daerah yang lain. Penggunaan teknologi informasi dalam pelestarian dan memberikan pengetahuan kepada masyarakat dapat dibuat dalam bentuk perangkat lunak yang dapat melakukan pencocokan pola gambar atau foto sekaligus melakukan klasifikasi tekstil tradisional. Input dalam penelitian ini berupa citra potongan tekstur yang bermotif. Perangkat lunak melalui proses pengenalan pola akan melakukan perhitungan dan menghasilkan nilai yang dapat dicocokkan pada database sample yang sebelumnya sudah diproses. Metode yang digunakan yaitu ekstraksi ciri warna dengan metode Local Color Histogram, ekstraksi ciri tekstur dengan metode Cooccurrence matrix, dan ekstrasi ciri bentuk dengan metode Canny Edge Detection. Masing-masing ekstraksi ciri akan menghasilkan vektor. Data yang digunakan terdiri dari 10

\footnotetext{
${ }^{1}$ Mahasiswa, Magister Teknik Elektro, Program Pasca Sarjana Universitas Udayana (e-mail: sukenada.andisana@gmail.com)

${ }^{2,3}$ Dosen, Magister Teknik Elektro, Universitas Udayana, Jln. P.B. Sudirman, Denpasar Bali (telp: 0361-239599; e-mail: msudarma@unud.ac.id,oka.widyantara@unud.ac.id)
}

I Putu Gd Sukenada: Pengenalan dan Klasifikasi Citra Tekstil ... kelompok tekstil yaitu kain endek bali, songket bali, tenun dayak, tenun ikat, sasirangan, kain besurek, ulos, sutra bugis, kain gringsing. Metode klasifikasi dengan menggukanan K-Nearest Neighborhood (K-NN). Hasil penelitian menunjukan bahwa nilai rata-rata hasil yang dikenal sesuai dengan kelompok tekstil adalah $\mathbf{8 8 . 0 3 \%}$. Nilai tertinggi menggunakan ekstraksi ciri tekstur sebesar $\mathbf{9 9 . 3 7 \%}$ dan terendah $\mathbf{6 3 . 7 5 \%}$ dengan menggunakan ekstraksi ciri bentuk dan warna.

Kata Kunci- Co-occurrence matrix, Local Color Histogram, Canny Edge Detection, KNN, tekstil tradisional

\section{PENDAHULUAN}

Tekstil adalah bahan yang berasal dari serat yang diolah menjadi benang atau kain sebagai bahan untuk pembuatan busana dan berbagai produk kerajinan lainnya. Tekstil dapat dibedakan menjadi tekstil modern dan tekstil tradisional. Perbendaan mendasar antara tekstil modern dan tradisioanal adalah dari teknik pembuatan, bahan dan motifnya. Tekstil tradisional digunakan sebagai simbolis dan berbagai upacara adat, memiliki nilai-nilai sakral yang digunakan dalam kegiatan kebudayaan di daerah asal tekstil tersebut.

Penggunaan motif tekstil tradisional Indonesia dipengaruhi oleh unsur-unsur alam, lingkungan dan kebudayaan yang berkembang di masyarakat. Material, motif, dan teknik pembuatan tekstil tradisional dapat berbeda antara satu daerah dengan daerah yang lain. Konsep kosmologi alam juga memberikan karakteristik baik dari segi motif dan warna sesuai dengan daerah masing-masing. Tekstil tradisional yang berkembang di Indonesia mewakili daerah masing-masing dan memberikan ciri bagi daerah tersebut. Motif pada tekstil tradisional biasanya diambil dari lingkungan sekitar maupun dari cerita kepahlawanan seperti epos Ramayana dan Mahabharata atau cerita rakyat lainnya yang berkembang di masyarakat.

Pengetahuan tentang jenis dan sifat serat tekstil merupakan modal dasar bagi mereka yang akan terjun di industri tekstil dan fashion. Pengetahuan tentang jenis dan sifat serat tekstil sangat diperlukan untuk mengenali, memilih, memproduksi, menggunakan dan merawat berbagai produk tekstil seperti serat, benang, kain, pakaian dan tekstil lainnya [1]. Karakteristik dan sifat bahan tekstil sangat ditentukan oleh karakteristik dan sifat serat penyusunnya [2]. Disamping itu sifat-sifat bahan tekstil juga dipengaruhi oleh proses pengolahannya seperti dari serat dipintal menjadi benang, dari benang ditenun menjadi kain kemudian dilakukan proses penyempurnaan hingga menjadi produk jadi. Oleh karena itu untuk memahami lebih jauh tentang bahan tekstil diperlukan 
pengetahuan tentang karakteristik dan sifat berbagai jenis serat dan teknik pengolahannya menjadi bahan tekstil. Pengetahuan mengenai tekstil tradisional bisa diperoleh dengan memperlajari satu-persatu tekstil tradisional yang ada di Indonesia. Cara yang lain untuk mengetahui jenis tekstil adalah dengan membandingkan dengan data yang sudah ada. Proses identifikasi terkomputerisasi dapat dilakukan dengan membandingkan data input dengan sumber data yang sudah ada. Kemudahan menggunakan cara terkomputerisasi adalah hanya dengan memberikan input berupa citra tekstil, sistem akan membandingkan dengan data yang sudah ada berdasarkan pola, warna dan tekstur. Data yang memiliki kemiripan yang tinggi akan ditampilkan berserta informasi mengenai tekstil tersebut.

Penggunaan teknologi informasi dalam pelestarian dan memberikan pengetahuan kepada masyarakat dapat dibuat dalam bentuk perangkat lunak yang dapat melakukan pencocokan pola gambar atau foto sekaligus melakukan klasifikasi tekstil tradisional. Input dalam penelitian ini berupa citra potongan tekstur yang bermotif. Perangkat lunak melalui proses pengenalan pola akan melakukan perhitungan dan menghasilkan nilai yang dapat dicocokkan pada database sample yang sebelumnya sudah diproses. Jika ditemukan pola yang serupa atau yang mendekati dengan persentase tertentu, perangkat lunak akan menampilkan klasifikasi pola tersebut atau pola tekstil yang mendekati pola citra input. Informasi yang ditampilkan berupa citra atau gambar klsifikasi, informasi daerah, sejarah dan informasi lain yang berhubungan dengan tekstil output. Hasil dari penelitian ini dapat menjadi media untuk lebih mengenal tekstil tradisional yang dimiliki daerah-daerah di Indonesia yang menjadi budaya dan ciri khas daerah, dan sebagai perangkat lunak yang memiliki data lengkap dalam kontribusi melestarikan tekstil tradisional Indonesia. Perangkat lunak ini dirancang dengan sistem berbasis web agar dapat diakses dan digunakan lebih luas. Pengenalan pola pada penelitian ini menggunakan tiga komponen yaitu ekstraksi ciri warna, ekstraksi ciri tekstur, dan ekstraksi ciri bentuk. Sedangkan teknik klasifikasi dalam penelitian ini akan menggunakan metode K-NN

\section{KAJIAN PustakA}

\section{A. State Of Art Review}

Karmilasari dan Agus Sumarna dalam jurnal yang berjudul "Temu Kembali Citra Berbasis Konten Warna" tahun 2011 membandingkan metode Global Color Histogram (GCH) dengan Local Color Histogram ( $\mathrm{LCH}$ ) dan gabungan kedua metode itu. Kesimpulan dari penelitian dalam jurnal ini adalah temu kembali citra berbasis konten warna mendasari pencarian citra berdasarkan kemiripan sebaran warna antara citra query dan citra dalam database. kemiripan citra hasil query lebih banyak dihasilkan oleh metode local color historgram $(\mathrm{LCH})$ dibandingkan global color histogram $(\mathrm{GCH})$ atau gabungan keduanya. hal ini dikarenakan informasi yang dihasilkan LCH lebih detail karena berdasarkan blok-blok piksel [3].
Penelitian Ade Winarni dengan judul "Sistem Temu Kembali Citra Batik Dengan Algoritma Co-Occurrence Matrix Dan Klasifikasi K Nearest Neighbor" tahun 2012 dengan menggunakan algoritma Co-Occurrence Matrix. Hasil penelitian menunjukan bahwa nilai rata-rata yang diperoleh lebih dari $60 \%$. Nilai tertinggi menggunakan ekstraksi ciri warna yaitu sebesar $74.28 \%$ dan terendah $62.85 \%$ dengan menggunakan ekstraksi ciri bentuk [4].

Penelitian CH. Kavitha dengan judul "An Efficient Content Based Image Retrieval Using Color And Texture Of Image Sub-Blocks" tahun 2011 menggunakan metode co-occurrence matrix dan local HSV. Hasil pengujian adalah metode yang digabungkan dapat menghasilkan pengenalan citra dengan rata-rata presisi lebih tinggi dibandingkan tanpa digabungkan [5].

Penelitian Abdul Fadlil yang berjudul "Sistem Pengenalan Citra Jenis-Jenis Tekstil" tahun 2012 menggunakan metode histogram. Data yang digunakan sebagai standar refrensi sebanyak 5 sampel untuk masing-masing jenis kain yaitu blacu, finished dan rajut. Hasil pengujian sistem identifikasi citra kain menunjukkan tingkat akurasi yang tinggi $90 \%$ untuk ukuran citra asli 600x800 [6].

Melihat penelitian sebelumnya, ekstraksi ciri tekstur dengan metode Co-Occurence Matrix pada citra batik memiliki hasil rata-rata lebih dari $60 \%$ untuk temu kembali citra serta memiliki presisi tinggi. Ekstraksi ciri warna dengan LCH lebih baik dibandingkan dengan metode GCH, maka pada penelitian ini akan menekankan pada pengenalan pola untuk mengklasifikasikan atau menggambarkan sesuatu berdasarkan pengukuran kuantitatif fitur (ciri) atau sifat utama dari suatu objek [7] citra dengan objek yang digunakan adalah tekstil tradisional Indonesia dengan menggabungkan metode ekstraksi ciri warna Local Color Histogram, ekstraksi ciri tekstur Co-Occurrence Matrix, dan ekstraksi ciri bentuk Canny Edge Detection. Klasifikasi menggunakan metode kNearest Neighbors

\section{B. Kain Tradisional}

Kain adalah suatu bahan yang merupakan hasil dari tenunan benang [2]. Sedangkan kain tradisional adalah kain yang berasal dari budaya daerah lokal yang dibuat secara tradisional dan digunakan untuk kepentingan adat istiadat [1]. Kain tradisional Indonesia diantaranya yaitu: batik, tenun, dan ikat.

\section{METODE PENELITIAN}

\section{A. Gambaran Umum Sistem}

Pada sistem ini dilakukan dengan beberapa tahap, mulai dari pengumpulan data citra yang akan digunakan sebagai data latih dan data uji. Citra yang digunakan sebagai data latih terlebih dahulu disimpan ke dalam database dengan melalui proses ekstraksi ciri. Data latih melalui ekstraksi ciri warna dengan metode Local Color Histogram, ekstraksi ciri tekstur dengan metode Co-occurrence matrix, dan ekstrasi ciri bentuk dengan metode Canny Edge Detection. Masing-masing ekstraksi ciri akan menghasilkan vektor, kemudian vektor beserta informasi dari citra latih disimpan ke dalam basis data [4]. 
Proses pengujian melalui tahap yang sama seperti pada proses data latih. Vektor yang dihasilkan dari data uji akan dilakukan pengukuran kemiripan dengan menggunakan klasifikasi K-NN. Gambaran Umum Penelitian dapat dilihat pada gambar 1.

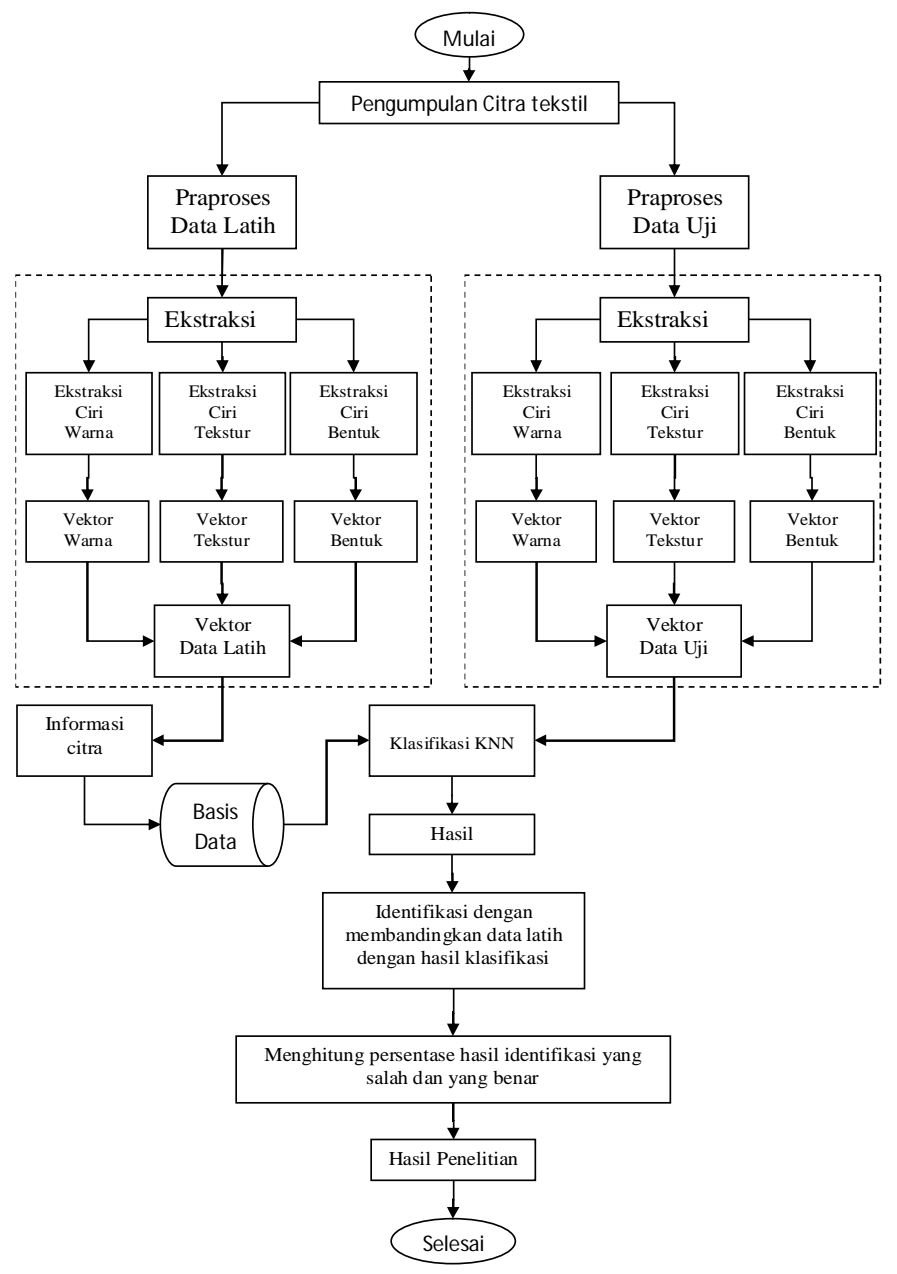

Gambar 1: Gambaran Umum Sistem

\section{B. Jenis Data}

Citra yang dipergunakan dalam penelitian ini adalah citra tekstil tradisional yang memiliki ragam hias yang terdiri dari hiasan-hiasan yang disusun sedemikian rupa sehingga membentuk satu kesatuan rancangan yang berpola. Data citra dalam bentuk file dengan ekstensi .jpg ukuran maksimal 300x300 pixel.

Jenis kain tradisional yang digunakan sebagai data latih dalam penelitian ini adalah 10 jenis yang terdiri dari kain batik, kain ulos, tenun ikat, kain gringsing, kain songket, kain sasirangan, kain tapis, kain basurek, kain tenun dayak, kain sutra bugis. Jumlah total data latih adalah 50 citra terdiri dari masing-masing 5 data untuk setiap jenis kain yang dijadikan sebagai data latih.

Data uji terdiri dari 40 citra yang akan diuji dengan mekanisme:

1. Mengubah orientasi citra dengan rotasi $90^{\circ}$ searah jarum jam, $90^{\circ}[8]$ berlawanan arah jarum jam, $180^{\circ}$

I Putu Gd Sukenada: Pengenalan dan Klasifikasi Citra Tekstil ...
2. Melakukan perubahan besar skala (cropping) pada citra untuk lebih fokus pada pola tertentu di dalam citra tersebut

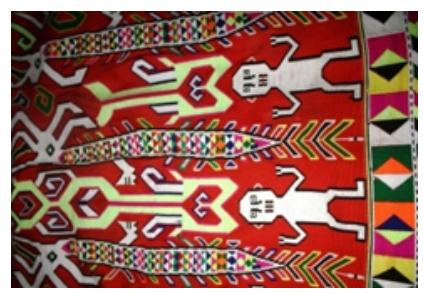

Gambar 2: Contoh data citra (Tenun Dayak)

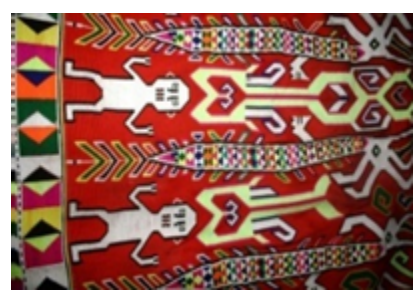

Gambar 3: Perubahan orientasi rotasi $180^{\circ}$

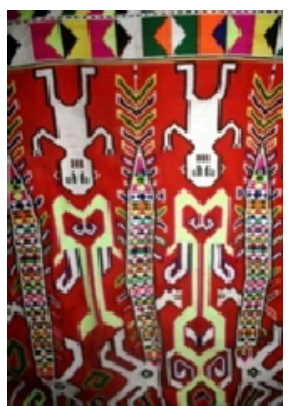

Gambar 4: Perubahan orientasi rotasi $90^{\circ}$

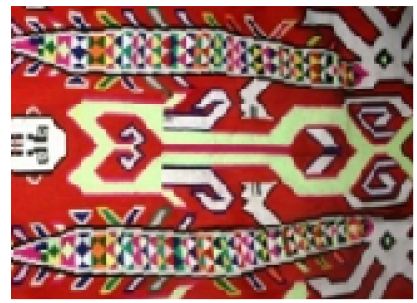

Gambar 5 : Cropping

\section{Tahapan Penelitian}

Sesuai dengan gambaran umum sistem, tahapannya adalah sebagai berilkut:

1. Input data latih berupa citra tekstil dan informasi daerah asal.

2. Ekstraksi citra warna menggunakan Local color histogram ( $L C H)$. LCH mencakup informasi tentang distribusi warna di berbagai daerah. Ini sama dengan Global color histogram $(\mathrm{GCH})$ [4] tapi pada awalnya gambar dibagi ke blok yang berbeda. Dimana setiap pasangan blok (salah satu dari blok di gambar pertama dan blok yang sama di gambar kedua) akan dihitung secara terpisah menggunakan GCH. Setelah itu total

p-ISSN:1693 - 2951; e-ISSN: 2503-2372 
jarak antara dua gambar adalah jumlah dari semua jarak GCH antara mereka.

3. Ekstraksi ciri tekstur dilakukan dengan Algoritma Gray Level Co-Occurrence Matrix (GLCM). Dengan langkah[3] [9]:

a. Menentukan kuantisasi dari tingkat keabuan

b. Menentukan co-occurrence matrix, yaitu menghitung dengan empat arah $0^{\circ}, 45^{\circ}, 90^{\circ}$, dan $135^{\circ}$. Jadi untuk setiap citra akan didapatkan empat co-occurrence matrix.

c. Untuk mengurangi dimensi dan lamanya waktu komputasi, maka dilakukan perhitungan rata-rata, dengan menggunakan rumus :

$f(x, y)=f(x, y) / R$

d. Energy, moment, entropy, probability, dihitung untuk setiap Co-Occurrence matrix, untuk lebih menghemat waktu komputasi jumlahkan terlebih dahulu empat nilai masing-masing arah $0^{\circ}, 45^{\circ}$, $90^{\circ}$, dan $135^{\circ}$.

4. Ekstraksi ciri bentuk dengan melakukan deteksi tepi citra menggunakan metode Canny Edge Detection. Deteksi Tepi Canny adalah algoritma deteksi tepi populer. Ini dikembangkan oleh John F. Canny pada tahun 1986. Deteksi tepi ini melalui beberapa tahap, yaitu: Noise Reduction, arena deteksi tepi rentan terhadap noise pada gambar, langkah pertama adalah untuk menghilangkan noise pada gambar dengan filter Gaussian 5x5; Menemukan gradient intensity gambar, gambar dihaluskan kemudian disaring dengan kernel Sobel di kedua arah horisontal dan vertikal untuk mendapatkan turunan pertama dalam arah horisontal $\left(G \_x\right)$ dan arah vertikal $\left(G \_y\right)$. Tepi gradien dan arah untuk setiap pixel dapat ditemukan dengan persamaan (2)

$$
\begin{gathered}
\text { Edge_Gradient }(G)=\sqrt{G_{x}^{2}+G_{y}^{2}} \\
\text { Angle }(\theta)=\tan \left(\frac{G_{y}}{G_{y}}\right)
\end{gathered}
$$

Arah gradien selalu tegak lurus terhadap tepi. Hal ini dibulatkan menjadi salah satu dari empat sudut yang mewakili vertikal, horisontal dan dua arah diagonal; Non-maximum Suppression, setelah mendapatkan besarnya gradien dan arah, scan penuh gambar dilakukan untuk menghilangkan piksel yang tidak diinginkan yang mungkin bukan merupakan tepi. Untuk setiap pixel, pixel diperiksa jika itu adalah maksimum lokal di lingkungan dalam arah gradien.
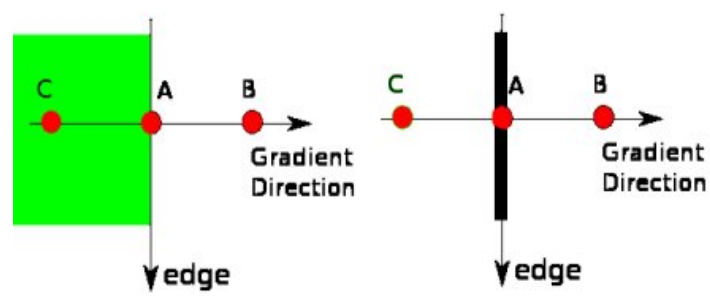

Gambar 6: Non-maximum Suppression
Titik A adalah di tepi (dalam arah vertikal). Arah gradien normal ke tepi. Titik B dan C berada di arah gradien. Jadi titik A diperiksa dengan titik B dan C untuk melihat apakah itu membentuk maksimum lokal. Jika demikian, hal ini dipertimbangkan untuk tahap berikutnya, jika tidak, itu dimasukkan ke nol; Hysteresis Thresholding, Tahap ini yang memutuskan semua edges yang benar dan mana egdes yang tidak. Perlu dua nilai ambang batas, minVal dan maxVal. Setiap tepi dengan intensitas gradien lebih dari maxVal adalah edge yang benar dan di bawah minVal adalah non-edges, sehingga dibuang. Edge yang terletak di antara dua ambang ini diklasifikasikan sebagai edge atau bukan berdasarkan konektivitas mereka. Jika terhubung ke piksel edges yang benar, maka dianggap sebagai bagian dari tepi. Jika tidak, maka dibuang.

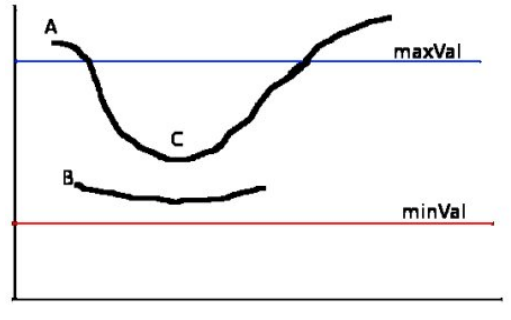

Gambar 7: Hysteresis Thresholding

Tepi A berada di atas maxVal, sehingga dianggap sebagai "sure-edge". Meskipun tepi C di bawah maxVal, itu terhubung ke tepi A, sehingga juga dianggap sebagai tepi valid dan kurva penuh. Tapi tepi $\mathrm{B}$, meskipun di atas minVal dan berada di kawasan yang sama dengan tepi $\mathrm{C}$, tidak terhubung ke "sureedge", sehingga dibuang. Jadi, sangat penting bahwa harus dipilih minVal dan maxVal yang sesuai untuk mendapatkan hasil yang benar. Tahap ini juga menghilangkan piksel noise yang kecil pada asumsi bahwa tepi garis panjang. Jadi akhirnya mendapatkan tepi yang kuat dalam gambar.

5. Ekstraksi ciri dalam bentuk vektor beserta informasi dari citra disimpan di database

6. Data citra yang telah diklasifikasikan secara manual digunakan sebagai data latih

7. Tahapan berikutnya adalah pengujian dengan menginputkan citra baru. Data citra uji melalui tahap yang sama dengan data latih yaitu ekstraksi ciri warna, tekstur dan bentuk.

8. Untuk dapat menemukan klasifikasi, data vektor data latih dengan data uji dihitung jaraknya dengan euclidean distance.

9. Klasifikasi dengan algoritma $K-N N$ dilakukan dengan mencari $\mathrm{k}$ buah tetangga terdekat dari data uji dan memilih kelas dengan anggota terbanyak. Tahapannya sebagai berikut:

a. Tentukan parameter $\mathrm{k}, \mathrm{k}$ merupakan jumlah tetangga terdekat

b. Hitung jarak antara citra uji dan semua sampel pelatihan

c. Urutkan jarak dan tentukan tetangga terdekat berdasarkan jarak k terdekat

d. Menentukan kelas dengan jumlah anggota terbanyak (dengan nilai k terbanyak yang ada dalam kelompok). 
e. Gunakan mayoritas terkecil dari kategori tetangga terdekat sebagai nilai prediksi dari citra uji.

10. Citra uji terdiri dari 4 cara yaitu: sesuai dengan citra asli, mengubah orientasi citra dengan rotasi $90^{\circ}$ searah jarum jam, $90^{\circ}$ berlawanan arah jarum jam, $180^{\circ}$, dan perubahan skala citra.

11. Pengujian dilakukan bedasarkan:
a. Bentuk
b. Tekstur
c. Warna
d. Gabungan bentuk dan tekstur
e. Gabungan bentuk dan warna
f. Gabungan tekstur dan warna
g. Gabungan bentuk, tekstur dan warna

12. Menghitung tingkat akurasi klasifikasi citra dengan metode $K-N N$

13. Penilai tingkat keefektifan proses temu kembali dari sejulah citra tekstil akan ditentukan dan dibandingkan melalui besaran akurasi yang berhasil dicapai dengan persamaan (3):

$$
\text { akurasi }=\frac{\sum \text { data uji yang dikenali }}{\sum \text { jumlah data uji }} \times 100 \%
$$

\section{IV.HASIL DAN PEMBAHASAN}

\section{A. Basis Data dan Form}

Pada penelitian ini menggunakan 2 tabel untuk menyimpan data latih dan menyimpan hasil uji. Struktur tabel dapat dilihat pada tabel I dan tabel II

TABEL I

TABEL DATA LATIH

\begin{tabular}{|l|l|l|l|}
\hline \multicolumn{1}{|c|}{ Nama field } & Tipe data & Ukuran & \multicolumn{1}{|c|}{ Keterangan } \\
\hline Id & Int & 11 & \multicolumn{1}{|c|}{ Nama tekstil } \\
\hline Nama & Varchar & 255 & $\begin{array}{l}\text { Direktori } \\
\text { penyimpanan data } \\
\text { latih }\end{array}$ \\
\hline Kategori & Varchar & 255 & $\begin{array}{l}\text { Infomasi dengan } \\
\text { berhubungan } \\
\text { citra }\end{array}$ \\
\hline PathFile & Text & - & Lokasi file citra fitur \\
\hline Bentuk & Text & - & $\begin{array}{l}\text { Vektor untuk fitur } \\
\text { bentuk fitur }\end{array}$ \\
\hline Tekstur & Text & - & $\begin{array}{l}\text { Vektor untuk fin } \\
\text { tekstur }\end{array}$ \\
\hline Warna & Text & - & $\begin{array}{l}\text { Vektor untuk } \\
\text { warna }\end{array}$ \\
\hline BentukTekstur & Text & - & $\begin{array}{l}\text { Vektor untuk fitur } \\
\text { bentuk dan tekstur }\end{array}$ \\
\hline BentukWarna & Text & - & $\begin{array}{l}\text { Vektor untuk fitur } \\
\text { bentuk dan warna }\end{array}$ \\
\hline TeksturWarna & Text & - & $\begin{array}{l}\text { Vektor untuk fitur } \\
\text { tekstur dan warna }\end{array}$ \\
\hline $\begin{array}{l}\text { BentukTeksturWar } \\
\text { na }\end{array}$ & Text & - & $\begin{array}{l}\text { Vektor untuk fitur } \\
\text { bentuk, tekstur dan } \\
\text { warna }\end{array}$ \\
\hline
\end{tabular}

I Putu Gd Sukenada: Pengenalan dan Klasifikasi Citra Tekstil ...
TABEL II

TABel Hasil Pengujian

\begin{tabular}{|c|c|c|c|}
\hline Nama field & Tipe data & Ukuran & Keterangan \\
\hline Id & Int & 11 & \\
\hline Nama & Varchar & 255 & Nama Tekstil \\
\hline Kategori & Varchar & 255 & $\begin{array}{l}\text { Direktori } \\
\text { penyimpanan data } \\
\text { latih }\end{array}$ \\
\hline Keterangan & Text & - & $\begin{array}{lr}\text { Infomasi } & \text { yang } \\
\text { berhubungan } & \text { dengan } \\
\text { citra } & \\
\end{array}$ \\
\hline PathFile & & & Lokasi file citra \\
\hline Bentuk & Text & - & 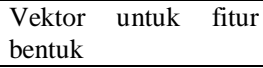 \\
\hline Tekstur & Text & - & $\begin{array}{ll}\text { Vektor untuk fitur } \\
\text { tekstur }\end{array}$ \\
\hline Warna & Text & - & $\begin{array}{l}\text { Vektor untuk fitur } \\
\text { warna }\end{array}$ \\
\hline BentukTekstur & Text & - & $\begin{array}{l}\text { Vektor untuk fitur } \\
\text { bentuk dan tekstur }\end{array}$ \\
\hline BentukWarna & Text & - & $\begin{array}{l}\text { Vektor untuk fitur } \\
\text { bentuk dan warna }\end{array}$ \\
\hline TeksturWarna & Text & - & $\begin{array}{l}\text { Vektor untuk fitur } \\
\text { tekstur dan warna }\end{array}$ \\
\hline $\begin{array}{l}\text { BentukTeksturWar } \\
\text { na }\end{array}$ & Text & - & $\begin{array}{llr}\text { Vektor untuk fitur } \\
\text { bentuk, tekstur dan } \\
\text { warna }\end{array}$ \\
\hline WaktuProses & Decimal & - & $\begin{array}{l}\text { Waktu saat proses } \\
\text { temu kembali }\end{array}$ \\
\hline Hasil & Text & & $\begin{array}{l}\text { Hasil berupa Id Citra } \\
\text { data latih }\end{array}$ \\
\hline
\end{tabular}

Data latih diinputkan melalui form input data latih dengan proses ekstrasi ciri dan menyimpan hasilnya ke dalam database berupa vektor. Form input data latih dapat dilihat pada gambar 8

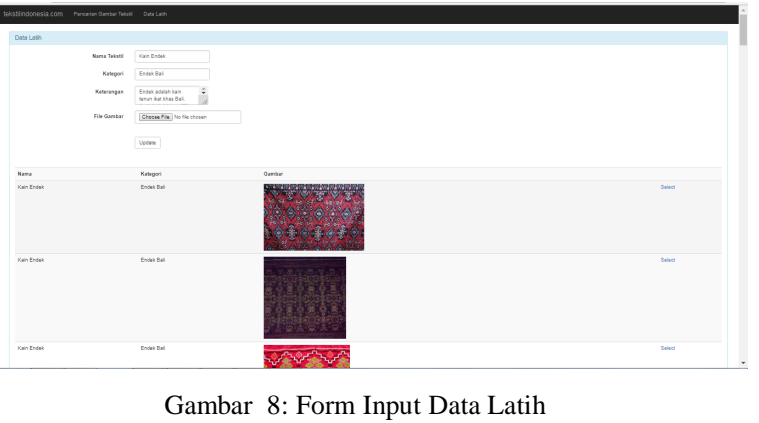

Pengujian dilakukan untuk masing-masing dan gabungan ekstraksi ciri. Form untuk melakukan pengujian dapat dilihat pada gambar 9

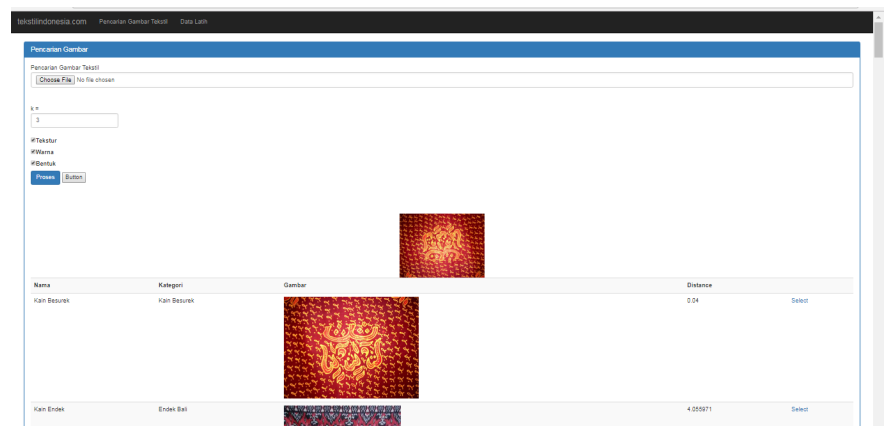

Gambar 9: Form pengujian

p-ISSN:1693 - 2951; e-ISSN: 2503-2372 


\section{B. Hasil identifikasi dengan ekstraksi ciri bentuk, warna dan tekstur}

Penggabungan vektor dengan cara menggabungkan langsung vektor dari ekstraksi ciri sehingga panjang vektor setelah digabungkan menjadi bertambah. Sebagai contoh: vektor ekstraksi ciri dari gambar 10 adalah:

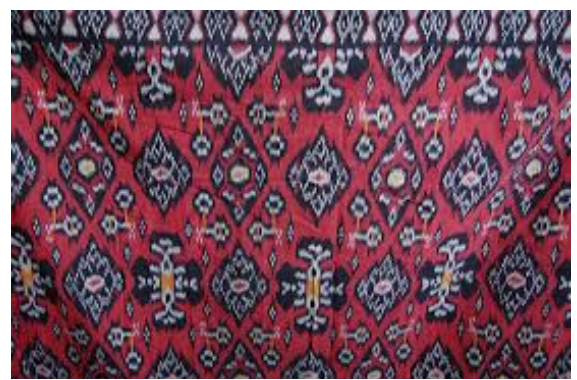

Gambar 10: Data latih kain endek

1. Vektor ekstrasi ciri bentuk:

0.23136731591523488;0.47333402629375387;0.2952986862221007;

2. Vektor ekstrasi ciri warna:

$0.09 ; 0.01 ; 0 ; 0 ; 0.01 ; 0.01 ; 0 ; 0 ; 0 ; 0 ; 0 ; 0 ; 0 ; 0 ; 0 ; 0 ; 0.04 ; 0.01 ; 0 ; 0 ; 0 ; 0.04 ; 0.01 ; 0$ $; 0 ; 0 ; 0.01 ; 0 ; 0 ; 0 ; 0 ; 0 ; 0.02 ; 0.02 ; 0 ; 0 ; 0.01 ; 0.01 ; 0.01 ; 0 ; 0 ; 0 ; 0.03 ; 0.01 ; 0 ; 0 ; 0$; $0.01 ; 0 ; 0.01 ; 0 ; 0 ; 0 ; 0 ; 0.01 ; 0 ; 0 ; 0 ; 0.01 ; 0.01 ; 0 ; 0 ; 0 ; 0.01 ; 0.06 ; 0.02 ; 0 ; 0 ; 0.01$ $0.01 ; 0 ; 0 ; 0 ; 0 ; 0 ; 0 ; 0 ; 0 ; 0 ; 0 ; 0.03 ; 0.02 ; 0 ; 0 ; 0 ; 0.04 ; 0.01 ; 0 ; 0 ; 0 ; 0.01 ; 0 ; 0 ; 0 ; 0 ; 0$ $0.01 ; 0.03 ; 0 ; 0 ; 0 ; 0.02 ; 0.01 ; 0 ; 0 ; 0.01 ; 0.03 ; 0.01 ; 0 ; 0 ; 0 ; 0.01 ; 0 ; 0.01 ; 0 ; 0 ; 0 ; 0$. $01 ; 0.01 ; 0 ; 0 ; 0 ; 0.01 ; 0.01 ; 0 ; 0 ; 0 ; 0.01 ; 0.04 ; 0.02 ; 0 ; 0 ; 0 ; 0.01 ; 0 ; 0 ; 0 ; 0 ; 0 ; 0 ; 0 ; 0$ $; 0 ; 0 ; 0.02 ; 0.03 ; 0 ; 0 ; 0 ; 0.04 ; 0.01 ; 0 ; 0 ; 0 ; 0.01 ; 0 ; 0 ; 0 ; 0 ; 0 ; 0.01 ; 0.02 ; 0 ; 0 ; 0 ; 0.0$ $3 ; 0.01 ; 0 ; 0 ; 0 ; 0.04 ; 0.01 ; 0 ; 0 ; 0.01 ; 0.01 ; 0 ; 0.01 ; 0 ; 0 ; 0 ; 0.01 ; 0.01 ; 0 ; 0 ; 0 ; 0.01$ $0.01 ; 0 ; 0 ; 0 ; 0.02 ; 0.04 ; 0.03 ; 0 ; 0 ; 0 ; 0.01 ; 0 ; 0 ; 0 ; 0 ; 0 ; 0 ; 0 ; 0 ; 0 ; 0 ; 0.02 ; 0.02 ; 0 ; 0$; $0 ; 0.03 ; 0.01 ; 0 ; 0 ; 0 ; 0.01 ; 0 ; 0 ; 0 ; 0 ; 0 ; 0.01 ; 0.02 ; 0 ; 0 ; 0 ; 0.03 ; 0.01 ; 0 ; 0 ; 0 ; 0.03 ; 0$ $.01 ; 0 ; 0 ; 0 ; 0.01 ; 0 ; 0.01 ; 0 ; 0 ; 0 ; 0.01 ; 0.01 ; 0 ; 0 ; 0 ; 0.01 ; 0.01 ; 0 ; 0 ; 0 ; 0.01$;

3. Vektor ekstrasi ciri tektur:

$0.01 ; 33.94 ; 0.1 ; 9.63 ; 0.01 ; 0.01 ; 42.52 ; 0.08 ; 9.73 ; 0.01 ; 0.01 ; 45.15 ; 0.07 ; 9$. $73 ; 0.01 ; 0.01 ; 44.83 ; 0.07 ; 9.7 ; 0.01$;

4. Vektor ekstrasi ciri warna dan bentuk:

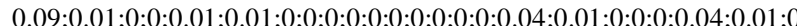
$; 0 ; 0 ; 0.01 ; 0 ; 0 ; 0 ; 0 ; 0 ; 0.02 ; 0.02 ; 0 ; 0 ; 0.01 ; 0.01 ; 0.01 ; 0 ; 0 ; 0 ; 0.03 ; 0.01 ; 0 ; 0 ; 0$; $0.01 ; 0 ; 0.01 ; 0 ; 0 ; 0 ; 0 ; 0.01 ; 0 ; 0 ; 0 ; 0.01 ; 0.01 ; 0 ; 0 ; 0 ; 0.01 ; 0.06 ; 0.02 ; 0 ; 0 ; 0.01$ $0.01 ; 0 ; 0 ; 0 ; 0 ; 0 ; 0 ; 0 ; 0 ; 0 ; 0 ; 0.03 ; 0.02 ; 0 ; 0 ; 0 ; 0.04 ; 0.01 ; 0 ; 0 ; 0 ; 0.01 ; 0 ; 0 ; 0 ; 0 ; 0$ $0.01 ; 0.03 ; 0 ; 0 ; 0 ; 0.02 ; 0.01 ; 0 ; 0 ; 0.01 ; 0.03 ; 0.01 ; 0 ; 0 ; 0 ; 0.01 ; 0 ; 0.01 ; 0 ; 0 ; 0 ; 0$. $01 ; 0.01 ; 0.23136731591523488 ; 0.47333402629375387 ; 0.2952986862$ 221007;

5. Vektor ekstrasi ciri warna dan tektur:

$0.09 ; 0.01 ; 0 ; 0 ; 0.01 ; 0.01 ; 0 ; 0 ; 0 ; 0 ; 0 ; 0 ; 0 ; 0 ; 0 ; 0 ; 0.04 ; 0.01 ; 0 ; 0 ; 0 ; 0.04 ; 0.01 ; 0$ $; 0 ; 0 ; 0.01 ; 0 ; 0 ; 0 ; 0 ; 0 ; 0.02 ; 0.02 ; 0 ; 0 ; 0.01 ; 0.01 ; 0.01 ; 0 ; 0 ; 0 ; 0.03 ; 0.01 ; 0 ; 0 ; 0 ;$ $0.01 ; 0 ; 0.01 ; 0 ; 0 ; 0 ; 0 ; 0.01 ; 0 ; 0 ; 0 ; 0.01 ; 0.01 ; 0 ; 0 ; 0 ; 0.01 ; 0.06 ; 0.02 ; 0 ; 0 ; 0.01 ;$ $0.01 ; 0 ; 0 ; 0 ; 0 ; 0 ; 0 ; 0 ; 0 ; 0 ; 0 ; 0.03 ; 0.02 ; 0 ; 0 ; 0 ; 0.04 ; 0.01 ; 0 ; 0 ; 0 ; 0.01 ; 0 ; 0 ; 0 ; 0 ; 0$ $0.01 ; 0.03 ; 0 ; 0 ; 0 ; 0.02 ; 0.01 ; 0 ; 0 ; 0.01 ; 0.03 ; 0.01 ; 0 ; 0 ; 0 ; 0.01 ; 0 ; 0.01 ; 0 ; 0 ; 0 ; 0$. $01 ; 0.01 ; 0.01 ; 33.94 ; 0.1 ; 9.63 ; 0.01 ; 0.01 ; 42.52 ; 0.08 ; 9.73 ; 0.01 ; 0.01 ; 45.15$ $; 0.07 ; 9.73 ; 0.01 ; 0.01 ; 44.83 ; 0.07 ; 9.7 ; 0.01$;

6. Vektor ekstrasi ciri bentuk dan tektur:

$0.23136731591523488 ; 0.47333402629375387 ; 0.2952986862221007$; $0.01 ; 33.94 ; 0.1 ; 9.63 ; 0.01 ; 0.01 ; 42.52 ; 0.08 ; 9.73 ; 0.01 ; 0.01 ; 45.15 ; 0.07 ; 9$. $73 ; 0.01 ; 0.01 ; 44.83 ; 0.07 ; 9.7 ; 0.01$;

7. Vektor ekstrasi ciri warna, bentuk dan tektur:

$0.09 ; 0.01 ; 0 ; 0 ; 0.01 ; 0.01 ; 0 ; 0 ; 0 ; 0 ; 0 ; 0 ; 0 ; 0 ; 0 ; 0 ; 0.04 ; 0.01 ; 0 ; 0 ; 0 ; 0.04 ; 0.01 ; 0$ $; 0 ; 0 ; 0.01 ; 0 ; 0 ; 0 ; 0 ; 0 ; 0.02 ; 0.02 ; 0 ; 0 ; 0.01 ; 0.01 ; 0.01 ; 0 ; 0 ; 0 ; 0.03 ; 0.01 ; 0 ; 0 ; 0 ;$ $0.01 ; 0 ; 0.01 ; 0 ; 0 ; 0 ; 0 ; 0.01 ; 0 ; 0 ; 0 ; 0.01 ; 0.01 ; 0 ; 0 ; 0 ; 0.01 ; 0.06 ; 0.02 ; 0 ; 0 ; 0.01$; $0.01 ; 0 ; 0 ; 0 ; 0 ; 0 ; 0 ; 0 ; 0 ; 0 ; 0 ; 0.03 ; 0.02 ; 0 ; 0 ; 0 ; 0.04 ; 0.01 ; 0 ; 0 ; 0 ; 0.01 ; 0 ; 0 ; 0 ; 0 ; 0$;
$0.01 ; 0.03 ; 0 ; 0 ; 0 ; 0.02 ; 0.01 ; 0 ; 0 ; 0.01 ; 0.03 ; 0.01 ; 0 ; 0 ; 0 ; 0.01 ; 0 ; 0.01 ; 0 ; 0 ; 0 ; 0$. $01 ; 0.01 ; 0.23136731591523488 ; 0.47333402629375387 ; 0.2952986862$ $221007 ; 0.01 ; 33.94 ; 0.1 ; 9.63 ; 0.01 ; 0.01 ; 42.52 ; 0.08 ; 9.73 ; 0.01 ; 0.01 ; 45.15$ $; 0.07 ; 9.73 ; 0.01 ; 0.01 ; 44.83 ; 0.07 ; 9.7 ; 0.01$;

Hasil pengujian dengan ekstraksi ciri bentuk, warna dan tekstur dengan dengan $\mathrm{KNN}$, citra yang paling banyak dikenal sesuai kelompok adalah kain endek, tapis, tenun dayak. Citra yang paling sedikit dikenal sesuai kelompok adalah songket bali dapat dilihat pada tabel III.

TABEL III

Hasil Pengujian Gabungan Ekstrasi Ciri Warna, Tekstur, Bentuk

\begin{tabular}{|l|c|c|c|c|c|c|c|c|c|}
\hline \multirow{2}{*}{ Kelompok Tekstil } & \multirow{2}{*}{$\begin{array}{c}\text { Jumlah } \\
\text { Data Uji }\end{array}$} & \multicolumn{2}{|c|}{ K=3 } & \multicolumn{2}{c|}{ K=7 } & \multicolumn{2}{c|}{ K=10 } & \multicolumn{2}{c|}{ K=15 } \\
\cline { 3 - 10 } & $\begin{array}{c}\text { Sesuai } \\
\text { Kelompok }\end{array}$ & $\begin{array}{c}\text { Tidak } \\
\text { Dikenal }\end{array}$ & $\begin{array}{c}\text { Dikenal } \\
\text { Sesuai } \\
\text { Kelompok }\end{array}$ & $\begin{array}{c}\text { Tidak } \\
\text { Dikenal }\end{array}$ & $\begin{array}{c}\text { Dikenal } \\
\text { Sesuai } \\
\text { Kelompok }\end{array}$ & $\begin{array}{c}\text { Tidak } \\
\text { Dikenal }\end{array}$ & $\begin{array}{c}\text { Dikenal } \\
\text { Sesuai } \\
\text { Kelompok }\end{array}$ & $\begin{array}{c}\text { Tidak } \\
\text { Dikenal }\end{array}$ \\
\hline Kain Endek & 4 & 4 & 0 & 4 & 0 & 4 & 0 & 4 & 0 \\
\hline Kain Besurek & 4 & 3 & 1 & 3 & 1 & 3 & 1 & 4 & 0 \\
\hline Kain Gringsing & 4 & 3 & 1 & 4 & 0 & 4 & 0 & 4 & 0 \\
\hline Sasirangan & 4 & 3 & 1 & 3 & 1 & 4 & 0 & 4 & 0 \\
\hline Songket Bali & 4 & 2 & 2 & 3 & 1 & 4 & 0 & 4 & 0 \\
\hline Sutra Bugis & 4 & 3 & 1 & 4 & 0 & 4 & 0 & 4 & 0 \\
\hline Tapis & 4 & 4 & 0 & 4 & 0 & 4 & 0 & 4 & 0 \\
\hline Tenun Dayak & 4 & 4 & 0 & 4 & 0 & 4 & 0 & 4 & 0 \\
\hline Tenun Ikat & 4 & 3 & 1 & 4 & 0 & 4 & 0 & 4 & 0 \\
\hline Ulos & 4 & 4 & 0 & 4 & 0 & 4 & 0 & 4 & 0 \\
\hline Total & 40 & 33 & 7 & 37 & 3 & 39 & 1 & 40 & 0 \\
\hline Akurasi (\%) & & 82.5 & 17.5 & 92.5 & 7.5 & 97.5 & 2.5 & 100 & 0 \\
\hline
\end{tabular}

Hasil pengujian yang dilakukan untuk masing-masing ekstraksi ciri dan gabungan estraksi ciri dapat dilihat pada table IV. Nilai akurasi dari pengujian menunjukkan ekstraksi ciri tektur memiliki akurasi $100 \%$ untuk $\mathrm{k}=7, \mathrm{k}=10$ dan $\mathrm{k}=15$. Nilai akurasi gabungan ekstraksi ciri bentuk dan warna memiliki akurasi paling rendah $35 \%$ untuk k-3.

Pada uji coba, kain gringsing dan kain endek memiliki nilai akurasi yang tinggi, hal ini dikarenakan motif kain gringsing dan kain endek pada citra latih memiliki kemiripan pada pola belah ketupat. Perbandingan kain gringsing dan kain endek dapat dilihat pada gambar 11 dan 12 .

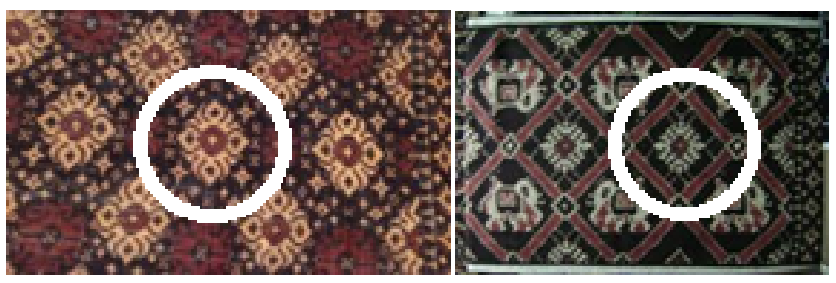

Gambar 11 Kain Gringsing
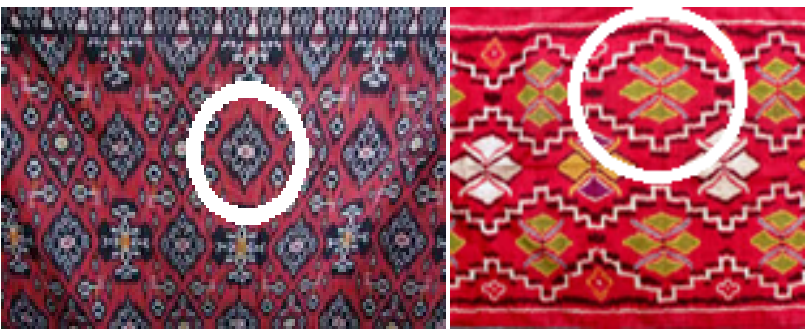

Gambar 12: Kain Endek 
Rata-Rata Hasil PenguJian

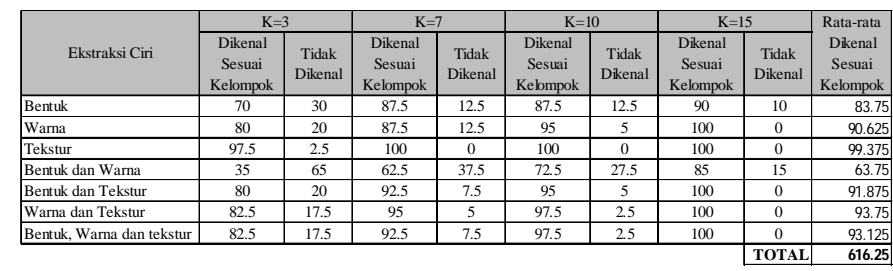

Nilai rata-rata hasil pengujian keseluruhan diperoleh dengan menjumlahkan nilai yang dikenal sesuai kelompok, untuk keseluruhan nilai $\mathrm{k}$ pada setiap pengujian ekstraksi ciri yang berjumlah 7 pengujian. Nilai rata-rata hasil yang dikenal sesuai kelompok adalah $616.25 / 7=88.03$.

\section{KESIMPULAN}

Berdasarkan penelitian yang telah dilakukan dapat disimpulkan:

1. Hasil penelitian menunjukan bahwa nilai rata-rata hasil yang dikenal sesuai dengan kelompok tekstil adalah $88.03 \%$. Nilai tertinggi menggunakan ekstraksi ciri tekstur sebesar $99.37 \%$ dan terendah $63.75 \%$ dengan menggunakan ekstraksi ciri bentuk dan warna.

2. Penggabungan ekstraksi ciri tektur, warna, dan bentuk dengan menggunakan nilai vektor yang diperoleh dari histogram, hasil temu kembali tidak lebih akurat dibandingkan hanya dengan menggunakan ekstraksi ciri tekstur.

\section{REFERENSI}

[1] Kamila, Mika. Ragam Kain Tradisional Nuasantara, Jakarta: Bee Media Indonesia, 2008.

[2] Poespo. Puspa Ragam Busana Pemilihan Ragam Bahan Tekstil, 2005.

[3] Karmilasari, Agus Sumarna, Temu Kenali Citra Berbasis Konten Warna, Seminar Nasional Aplikasi Teknologi Informasi, 2011

[4] Ade Winarni. "Sistem Temu Kembali Citra Batik Dengan Algoritma Co-Occurrence Matrix Dan Klasifikasi K Nearest Neighbor'[Tesis]. Denpasar:Unud, 2012.

[5] Ch.kavitha, prabhakara rao, "An efficient content based Image retrieval using color And texture of image subblocks", Vol 3, IJEST, 2011.

[6] Abdul Fadlil. Sistem Pengenalan Citra Jenis-Jenis Tekstil, Vol 10, No 1, Universitas Ahmad Dahlan,

[7] Putra, Darma .2010. Pengolahan Citra Digital :ANDI OFFSET , Yogyakarta

[8] Arisandi, Nanik, "Pengenalan Motif Batik Menggunakan Metode Rotated Wavelet Filter dan Neural Network", Vol 9, ITS, Surabaya, 2011

[9] Agung Sugiartha, "Ekstraksi Fitur Warna, Tekstur dan Bentuk untuk Clustered-Based Retrieval of Images(CLUE)", Teknologi Elektro, Vol. 16, No1, Unud, Denpasar, 2017 
\{ Halaman ini sengaja dikosongkan\} 